Conference Proceedings Paper

\title{
Historical Composition of Zooplankton as an Indicator of Eutrophication in Tropical Aquatic Systems: the Case of Lake Amatitlán, Central America
}

\author{
Sarahi Jaime ${ }^{1 *}$, Adrián Cervantes-Martínez ${ }^{1}$ Martha A. Gutiérrez-Aguirre ${ }^{1}$, Eduardo Suárez- \\ Morales ${ }^{2}$, Julio R. Juárez-Pernillo ${ }^{3}$, Elena M. Reyes-Solares ${ }^{3}$ \\ 1 Universidad de Quintana Roo (UQROO), Avenida Andrés Quintana Roo. Col. San Gervasio, Cozumel \\ 77600, Quintana Roo, Mexico \\ 2 El Colegio de la Frontera Sur (ECOSUR), Avenida Centenario Km 5.5, Chetumal 77014, Quintana Roo, \\ Mexico \\ 3 Autoridad para el Manejo Sustentable de la cuenca del lago de Amatitlán (AMSA); Kilómetro 22 CA-9, \\ Bárcenas Villanueva, 6624-1700, Guatemala \\ * Correspondence: sarajaime33a@gmail.com; Tel.: +52-987-114-6415
}

\begin{abstract}
Zooplankton biodiversity is deemed as a realiable indicator of water quality. For 40 years, the Guatemalan lake Amatitlán has shown signs of eutrophication, with measurable impacts on the local zooplankton diversity. Biotic and abiotic variables were surveyed at four sites of lake Amatitlán (Este Centro, Oeste Centro, Bahía Playa de Oro and Michatoya) in 2016 and 2017. The species richness and abundance of rotifers, cladocerans, and copepods were analyzed. The dynamic composition of zooplankton was studied and the system environmental parameters were analyzed in two seasons (rainy and dry season) for both years. Characteristical values of eutrophied tropical systems were obtained, with high rotifer diversity (11 species) and abundance. At present, the rotifers Brachionus havanaensis (109 ind/L) and Keratella americana (304 ind/L) were the most abundant species in the system. The copepod Mastigodiaptomus amatitlanensis considered as endemic in 1941 is absent nowadays, but we reported the unprecedented occurrence of two exotic copepods (i. e., Thermocyclops crassus, Mesocyclops thermocyclopoides) for lake Amatitán and all Guatemala. The presence of large zooplankton like adults and immature copepods (Arctodiaptomus dorsalis) and cladocerans (Ceriodaphnia sp.), in site "Este Centro", indicates a relatively healthy community and represents a focal point for the conservation for this lake.
\end{abstract}

Keywords: conservation; eutrophication; exotic species; tropical lakes; zooplankcton.

\section{Introduction}

Zooplankton knowledge is emerging in neotropical regions with scarce and fragmented studies. Therefore, species richness may be underestimated due to the diversity of bioregions and scarce of zooplankton taxonomist (i. e Suárez-Morales et al., 1996[1]) [2,3]. Nevertheless, habitat destruction and the occurrence of exotic species are factors that engage biodiversity, ecosystems, and environmental services.

Lake Amatitlán is Guatemala's the fourth largest lake and one of the most emblematic waterbodies for this country, with an area of $15.2 \mathrm{~km}^{2}$ and $11 \mathrm{~km}$ length, is placed on an altitude of 1,186 meters above sea level (m.a.s.l.)[4,5]. For over 4 decades, lake Amatitlán has shown signs of eutrophication related probably, to anthropic factors (i. e. population growth, use of water for agricultural irrigation and urbanization around the lake). The progress toward eutrophication on this Guatemalan lake, is related to the income of $50 \%$ of the residual waters from Guatemala City [6-8]. 
Due to this, some actions have been arisen to address this problem, either from the governmental level (Autoridad para el Manejo Sustentable de la cuenca del lago Amatitlán, AMSA 1996) and some descriptive studies of the lake considering the zooplankton biodiversity in the region, such as Juday (1915) [9], Basterrechea-Díaz (1997) [6], Elías-Gutiérrez et al. (2006)[10], García-Morales \& ElíasGutiérrez (2007)[11] and Brandorff (2012) [12]. Nevertheless, related studies related with tropical epicontinental waterbodies have been more focused on environmental factors rather than in the biological attributes or systems general limnology [13,14]; thus, biodiversity and species richness of zooplankton in all Guatemala is poorly known [4,5]. With a historical and actual review of zooplankton biodiversity as well as an actual knowledge of the environmental conditions, we present the distribution, species richness, and spacial and temporal abundance of zooplankton and its relationship with environmental variables. We report the occurrence of two cyclopoid exotic species (Mesocyclops thermocyclopoides (Fischer, 1853) and Termocyclops crassus Harada, 1931) and the absence of the calanoid copepod Mastigodiaptomus amatitlanensis (Wilson, 1941) that was used to be recorded as endemic of the lake $[15,16]$

\section{Experiments}

Study sites and sampling methods

Four sampled sites were considered (Figure 1): Este Centro (EC), Oeste Centro (OC), Bahía Playa de Oro (BPO) and Michatoya (MICH). The latter two sites are connected to Villalobos river and Michatoya river, respectively [5]. Water samples for biotic and abiotic variables were collected for 2016 and 2017 in the rainy (May-October) and dry seasons (November-April).

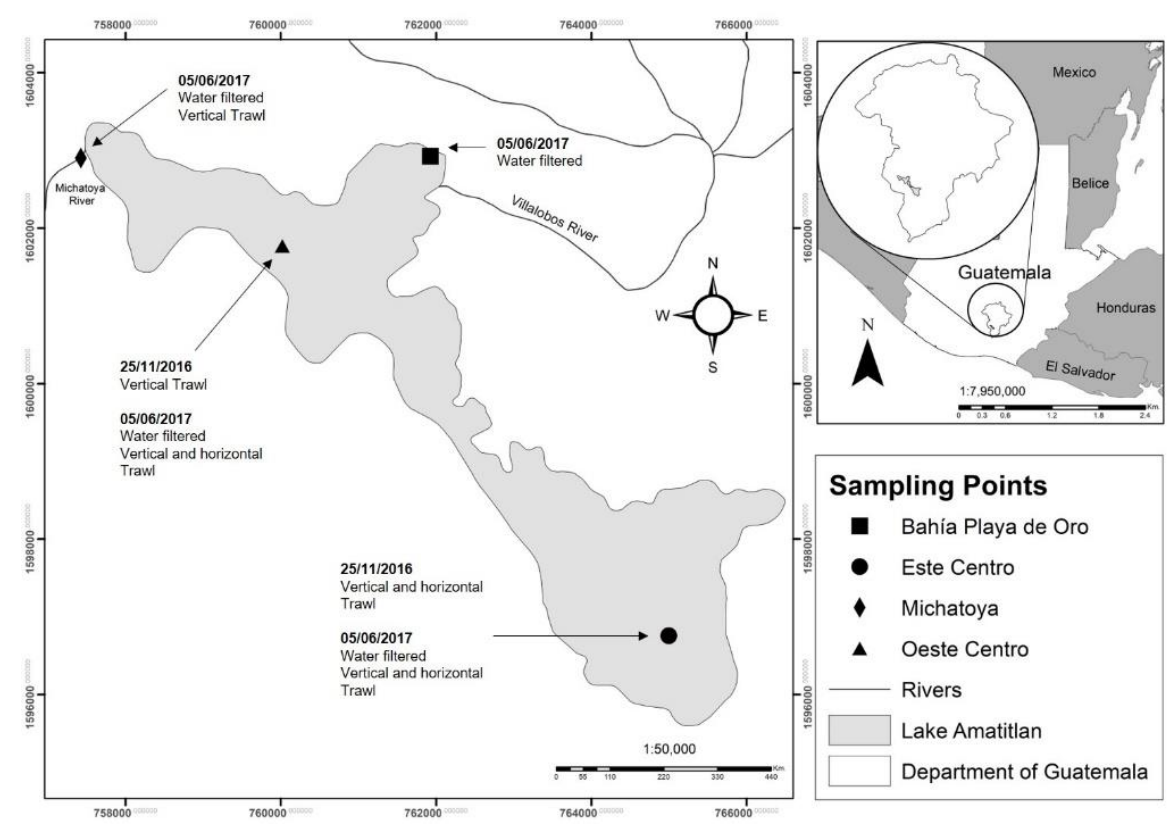

Figure 1. Location of lake Amatitlán and sampling points with information of biotic collection methods. Water filtered, vertical and horizontal trawls as defined by

Cervantes-Martínez \& Gutiérrez-Aguirre (2015) [2]

Biological samples $(n=8)$ were performed with a plankton net of $45 \mu \mathrm{m}$ mesh by vertical and horizontal trawls, filtering a known volume of water and fixed with $90 \%$ alcohol. As minimum 100 water litters were filtered for each sample. Abundance was standardized as org $\mathrm{L}^{-1}$ by total account of individuals in each sample. Abiotic variables were collected in situ: water temperature $\left({ }^{\circ} \mathrm{C}\right), \mathrm{pH}$, oxygen concentration $\mathrm{O}_{2}\left(\mathrm{mg} \mathrm{L}^{-1}\right)$, total dissolved solids $\left(\mathrm{mg} \mathrm{L}^{-1}\right)$, and conductivity $\left(\mu \mathrm{cm}^{-1}\right)$.

Zooplankton analysis 
Specific classification of Rotifera, Cladocera and Copepoda of recently collected samples (collected in 2016, and 2017) was done according to Koste (1978) [17], Fontaneto \& De Smet (2015) [18], Elías-Gutiérrez et al. (2008) [19] and Suárez-Morales et al. (2020) [20].

The presence/absence of the actual zooplancton inventory, was compared with the inventories studied by Juday (1915) [9], Basterrechea-Díaz (1997) [6], Wilson (1941) [15] and Brandorff (2012)[12] in order to analize the historical compositon of zooplankton of Amatitlan lake.

Physiochemical analysis

A Principal Component Analysis (PCA) was used to examine these environmental variables for all the sites. For this, all the information, except $\mathrm{pH}$, were transformed to $\log _{10}+1$ to normalize the data [21]. Statistical analysis was performed in Multi-Variate Statistic Package (MVSP, V 3.2).

\section{Results and discussion}

\subsection{Zooplankton biodiversity}

\subsubsection{Species richness}

15 species were found in the lake (Table 1$)$, rotifers presented the higesth species richness (80\%), while copepods presented the $20 \%$ of total species in the lake, cladocerans were practically absent with just one specimen of Ceriodaphnia sp. EC presented the highest species richness in the hole system (14 species), compared with $\mathrm{BPO}$ and $\mathrm{MICH}$ ( 9 and 8 species respectively). In EC was present the largest size species of the lake (Arctodiaptomus dorsalis) and the cyclopoid copepod Mesocyclops thermocyclopoides. The known total body length average of these species is $0.77-1.13 \mathrm{~mm}$ and $0.79-0.89$ $\mathrm{mm}$, respectively $[22,23]$.

Table 1 Current and historical records of zooplankton species richness. The actual recorded species in columns 1) $\mathrm{EC}$, 2) OC, 3) BPO and 4) MICH. Historical records in columns 5 to 8, according with Brandorff (2012) [12]; Basterrechea-Díaz (1997) [6]; Wilson (1941) [15]; and Juday (1915) [24], respectively. Presence (x), absence $(-)$, new registers $(*)$, possible extint species $(\dagger)$.

Species

\begin{tabular}{cccccccc}
\multicolumn{3}{c}{ Actual records } & \multicolumn{3}{c}{ Historical records } \\
1 & 2 & 3 & 4 & 5 & 6 & 7 & 8
\end{tabular}

Phylum: Rotifera

Monogononta: Ploimida

Family: Epiphanidae Harring, 1913

Epiphanes macroura Barrois \& Daday, 1894*

Family: Brachionidae Ehrenberg, 1838

Anuraeopsis fissa (Gosse, 1851)*

Brachionus angularis (Gosse, 1851) *

B. calyciflorus Pallas, 1766 *

B. plicatilis Müeller, 1786 *

B. havanaensis Rousselet, 1911*

Keratella spp

K. americana Carlin, 1943*

K. cochleraris (Gosse, 1851)

$\begin{array}{llllllll}\mathrm{x} & \mathrm{x} & - & - & - & - & - & - \\ - & - & - & - & - & - & - & - \\ \mathrm{x} & - & - & - & - & - & - & - \\ \mathrm{x} & \mathrm{x} & \mathrm{x} & \mathrm{x} & - & - & - & - \\ \mathrm{x} & \mathrm{x} & \mathrm{x} & \mathrm{x} & - & - & - & - \\ \mathrm{x} & - & - & \mathrm{x} & - & - & - & - \\ \mathrm{x} & \mathrm{x} & \mathrm{x} & \mathrm{x} & - & - & - & - \\ - & - & - & - & - & \mathrm{x} & - & - \\ \mathrm{x} & \mathrm{x} & \mathrm{x} & \mathrm{x} & - & - & - & - \\ - & - & - & - & - & - & - & \mathrm{x}\end{array}$

Family: Trichocercidae Harring, 1913

The 1st International Electronic Conference on Biological Diversity, Ecology, and Evolution, 15-31 March 2021 
Trichocerca cf. longiseta (Schrank, 1802)*

T. pusilla (Lauterborn, 1898)*

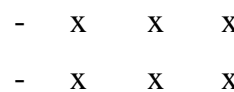

Family: Asplanchnidae Eckstein, 1883

Asplanchna sieboldi (Leydig, 1854)*

Flosculariaceae: Family: Trochosphaeridae Harring,

1913

Filinia longiseta (Ehrenberg, 1834)

F. terminalis (Plate, 1886) *

$\begin{array}{llllllll}\mathrm{X} & \mathrm{X} & \mathrm{X} & \mathrm{X} & - & - & - & \mathrm{X} \\ \mathrm{X} & \mathrm{X} & \mathrm{X} & - & - & - & - & -\end{array}$

\section{Subclass: Bdelloidea}

Bdelloidea*

Superclass: Crustacea

Brachiopoda: Cladocera: Anomopoda

Family: Daphniidae Straus, 1820

Daphnia sp.

D. hyalina Leydig, 1860

Ceriodaphnia sp.

C. lacustris Birge, 1893

C. pulchella Sars, 1862

Family: Bosminidae Sars, 1865

Bosmina longirostris O. F. Müeller, 1776

Family: Chydoridae Stebbing, 1902

Chydorus sphaericus (O.F. Müeller, 1785)

\section{Copepoda: Calanoida}

Family: Diaptomidae G.O. Sars, 1932

Subfamily: Diaptominae Kiefer, 1932

Arctodiaptomus dorsalis (Marsh, 1907)

Mastigodiaptomus albuquerquersis (Herrick, 1895)

M. amatitlanensis (Wilson, 1941) $\dagger$

\section{Copepoda: Cyclopoida}

Family: Cyclopidae Kiefer, 1927

Subfamily: Cyclopinae Kiefer, 1927

Thermocyclops crassus (Fischer, 1853)*

Mesocyclops thermocyclopoides Harada, 1931*

Nauplii

Juvenile Cyclopoid

Juvenile Calanoid

$\begin{array}{llllllll}- & \mathrm{x} & - & - & - & - & - & - \\ \mathrm{x} & - & - & - & - & - & - & - \\ \mathrm{x} & \mathrm{X} & \mathrm{X} & \mathrm{x} & - & \mathrm{X} & - & \mathrm{X} \\ \mathrm{x} & \mathrm{X} & \mathrm{X} & \mathrm{x} & - & - & - & - \\ \mathrm{x} & \mathrm{X} & \mathrm{X} & \mathrm{x} & - & - & - & -\end{array}$

Rotifers had the lowest species richness with three monogonont species since 1910 (Table 1). In this study, richness increased with 12 new reported species for the lake, including Bdelloidea. From 1915 to 1997 cladocerans presented the highest species richness with 7 known species, followed by 3 calanoid copepods reported: A. dorsalis, Mastigodiaptomus albuquerquensis, and the endemic $M$. amatitlanensis $[6,9,12,15]$. This latter species is considered as a possibly extinct [16], because since its description date by Wilson (1941) [15] it has not been recorded, including this study. Additionaly we 
report for the first time in Amatitlán lake, two cyclopoid copepods, considered as exotic species for America: Thermocyclops crassus (Euro-Asiatic species) and M. thermocyclopoides (Afro-Asiatic species) $[22,25]$.

\subsubsection{Species abundance}

Species with the highest abundance in all sites were the rotifers Brachionus havanaensis (109 ind/L) and Keratella americana (304 ind/L). The abundance of immature stages of cyclopoid and calanoid copepods were similar to the rotifers B. plicatilis $(0.12 \mathrm{ind} / \mathrm{L}), A$. sieboldi $(2.33 \mathrm{ind} / \mathrm{L})$, and $M$. thermocyclopoides $(0.06 \mathrm{ind} / \mathrm{L})$. This behavior has been reported in eutrophied tropical water bodies where the abundance of species with small sizes as rotifers is higher compared to largest species as cladocerans and copepods [26]. Species abundance behavior has a close relation with the eutrophication of the lake since the presence of organisms that conforms the microzooplankton (like rotifers) was considerably higher than species of larger sizes, with greater predominance in species characterized by filtering habits such as brachionids [18].

We present for the first time the occurrence of two exotic species for lake Amatitlán and all of Guatemala. M. thermocyclopoides is an Afro-Asian species probably introduced to America by human activities such as acuaculture, it has been registered in the state of Chiapas, Mexico, a border state with Guatemala [22]. Thermocyclops crassus is an Euro-Asiatic species considered as a species introduced to the West, with its first record in Mexican lagoons of the Tabasco state, with the causes of introduction similar to $M$. thermocyclopoides [25]

The possible cause why Ceriodaphnia could be practically absent, is due to the competition and size of the availability of food in the system caused by the eutrophication: species composition and zooplankton abundance are significantly influenced by the type and quality of food [27], eventually justifying the dominance of brachionid rotifers like B. havanaensis and K. americana. Thus, the trophic state is related to the size of the zooplankton that inhabits the waterbody, where it is observed that the higher level of eutrophication, the greater the abundance and species richness of microzooplankton such as rotifers and immature stages of copepods will be found [26].

\subsection{Physiochemical variables}

Environmental variables in the lake present evidence of eutrophication. For instance, in changes of $\mathrm{pH}$ values: 8.26 and 8.33 in both analized years, contrasting significantly with the values recorded in 1969 (7.70) [21], 1985-1995 (7.75) [6], and 2008 (9.3) [21]; It is well known that in oligotrophical systems, the $\mathrm{pH}$ values tend towards to neutrality, and this value rises when there is a higher primary production, with more basic values [28].

The variability in PCA of 2016 and 2017 (Figure 2) was mainly interpreted with pH parameter (36 and 37\%) and secondary by the water temperature (24 and 29\%) in the lake. In 2016 STD and conductivity were more related on axis 2 while in 2017, those variables were more related on axis 1; those parameters showed the highest eigenvalues in both years.

Two well-differentiated groups were found in both years of study: EC and OC represented a different distribution, in the same way, that $\mathrm{MICH}$ presented a separate grouping of $\mathrm{BPO}$, especially in 2016 (Figure 2A, 2B). 


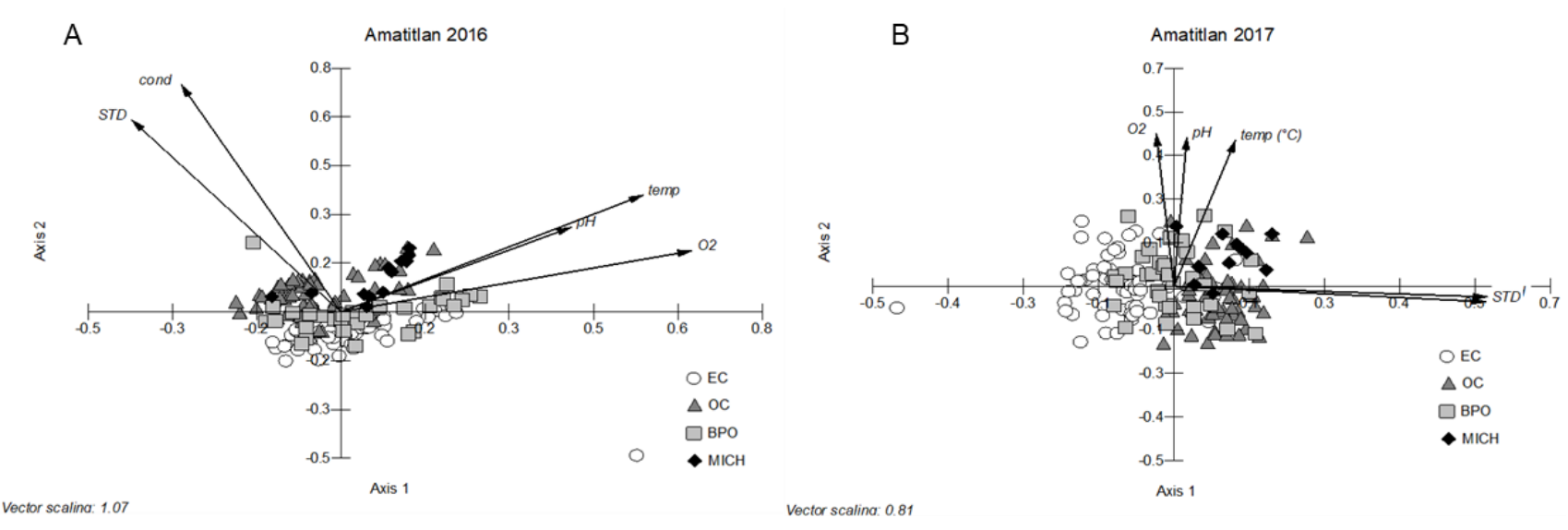

Figure 2 Principal Component Analysis (PCA) based on 5 physiochemical parameters of the four study sites in lake

Amatitlán. (A) 2016, (B) 2017. Symbols are the sampled points.

EC presented physical characteristics which influence its zonification due to the absence of direct water flows as rivers (like Villalobos in BPO and Michatoya in OC zone, Figure 1), it is isolated and divided, with a considerable distance to the closest site OC $(11.60 \mathrm{~km})$ [5]; which has allowed it to be an area with the best conservation status of the lake, where there are the greatest species richness and larger species, among them, A. dorsalis. This species is considered to be wide disperse in America [23] registered as an invasive exotic species in Asiatic waterbodies in Filipinas [29]. The environmental conditions of lake Amatitlán justify its presence, as it has a selective feeding of phytoplankton, thus, it is common in eutrophic environments as this lake.

\section{Conclusions}

Physiochemical changes in the lake have impacted the behavior of the zooplankton biodiversity, and have progressively changed the lake condition towards eutrophy. As the endemic species Mastigodiaptomus amatitlanensis has not been reported since its description date, probably is an extinct species. Lake Amatitlán showed more abundance of microzooplankton species dominated by rotifers (specially brachionids) and a diminution of larger species like cladocerans and copepods that are indicators of water quality per se. It is convenient to consider EC as a potential area for conservation since it presents better environmental conditions for the conservation and preservation of zooplankton biodiversity.

\section{Acknowledgments:}

We gratefully aknowledge the invitation of Dr. Manuel Elías-Gutiérrez to contribute in this congress and AMSA for all the biological material and data bases that made possible the present study. Anonymus reviewers made valuable comments and suggestions. University of Quintana Roo, Cozumel with the investigation group vulnerability of continental and coastal water systems and the National Council of Science and Technology (CONACYT) with the Investigator SNI-III Assistant Programm (Number 19812) gave financial support.

\section{Author Contributions:}

SJ wrote the paper, examine all zooplankton samples, identified zooplankton species, analyzed the physiochemical variables on the databases, and performed the statistical analyzes for both years of study. ACM provides the principal ideas and goals for this study. ACM, MAGA and ESM contributed to the writing of the paper providing information for this study, identified zooplankton species, contributed with the analysis of the results and revision of all the document. EMRS and JRJP contributed providing biological samples and abiotical variables databases for both years of study and with the analysis and revision of all the document. 
Conflicts of Interest: The authors declare no conflict of interest with the representations and interpretation of the results expressed in this paper, also, the founding sponsors had no role in the design of the study; in the analyses and interpretation of data; in the writing of the manuscript, and in the decision to publish the results.

\section{Abbreviations}

AMSA: Autoridad para el Manejo Sustentable de la cuenca del lago de Amatitlán;

CONACYT: Consejo Nacional de Ciencia y Tecnología

\section{References}

1 Suárez-Morales, E.; Reid, J. W.; Ilige, T.; Fiers, F. Catálogo de Los Copépodos (Crustacea) Continentales de La Península de Yucatán, México; Chetumal, Quintana Roo, México. Comisión Nacional para el Conocimiento y Uso de la Biodiversidad. 296 p., 1996.

2 Cervantes-Martínez, A.; Gutiérrez-Aguirre, M. A. Physicochemistry and Zooplankton of Two Karstic Sinkholes in the Yucatan Peninsula, Mexico. J. Limnol. 2015, 74 (2), 382-393. https://doi.org/10.4081/jlimnol.2014.976.

3 José de Paggi, S. B.; Wallace, R.; Fontaneto, D.; Marinone, M. C. Phylum Rotifera. In Thorp and Covich's Freshwater Invertebrates; Damborenea, C., Rogers, C. D., James, T., Eds.; n Diego, United States, Elsevier Science Publishing Co Inc.145-200., 2020; pp 145-200.

4 Ellenberg, R. L. Limnology of Lake Amatitlán in Guatemala and Its Eutrophication Process, Tesis de Doctorado, Technical University of Berlin. Berlín, Alemania 128 p., 2014.

5 Jiménez, S.; Juárez, J.; Trujillo, L.; Dubón, S.; Valenzuela, O.; M, C. A. Calidad de Agua de La Cuenca y Lago de Amatitlán; División de Control, Calidad Ambiental y Manejo de Lagos, Guatemala, 32 p., 2015.

6 Basterrechea-Díaz, M. El Lago de Amatitlán: Década de Estudios Limnológicos 1985-1995; Academia de Ciencias Médicas, Físicas y Naturales de Guatemala, 45 p.: Guatemala, 1997.

7 Sigui, N. ¿Por Qué Continúa La Contaminación de Aguas En Guatemala? Ciencia, Tecnol. y Salud 2016, 3 (2), 167-176.

8 Rodas-pernillo, E.; Vasquez-moscoso, C. A.; García, O. F. Dinámica Del Consumo y Aporte de Nutrientes de Fitoplancton, Dominado Por. Ciencia, Tecnol. y Salud 2020, 7, 2409-3459.

9 Juday, C. Limnological Studies on Some Lakes in Central America. Wisconsin Acad. Sci. Arts, Lett. 1915, 18, 214-250.

10 Elías-Gutiérrez, M.; Kotov, A. A.; Garfias-Espejo, T. Cladocera (Crustacea: Ctenopoda, Anomopoda) from Southern Mexico, Belize and Northern Guatemala, with Some Biogeographical Notes. Zootaxa 2006, No. 1119, 1-27.

11 García-Morales, A. E.; Elías-Gutiérrez, M. The Rotifer Fauna of Guatemala and Belize: Survey and Biogeographical Affinities. Rev. Biol. Trop. 2007, 55, 569-584.

Brandorff, G. O. Distribution of Some Calanoida (Crustacea: Copepoda) from the Yucatán Peninsula, Belize and Guatemala. Rev. Biol. Trop. 2012, 60 (1), 187-202.

Cervantes-Martìnez, A.; Elìas-Gutiéerrez, M.; Suárez-Morales, E. Limnological and Morphometrical Data of Eight Karstic Systems "cenotes" of the Yucatan Peninsula, Mexico, during the Dry Season (February-May, 2001). Hydrobiologia 2002, 482, 167-177.

14 Schmitter-Soto, J. J.; Comín, F. A.; Escobar-Briones, E.; Herrera-Silveira, J.; Alcocer, J.; Suárez-Morales, E.; Elías-Gutiérrez, M.; Díaz-Arce, V.; Marín, L. E.; Steinich, B. Hydrogeochemical and Biological Characteristics of Cenotes in the Yucatan Peninsula (SE Mexico). Hydrobiologia 2002, 467, 215-228. 
in the United States National Museum. J. Washingt. Acad. Sci. 1941, 31 (12), 509-515.

Gutiérrez-Aguirre, M. A.; Cervantes-Martínez, A.; Elías-Gutiérrez, M.; Lugo-Vázquez, A. Remarks on Mastigodiaptomus (Calanoida: Diaptomidae) from Mexico Using Integrative Taxonomy, with a Key of Identification and Three New Species. PeerJ 2020, No. 1. https://doi.org/10.7717/peerj.8416.

Koste, W. Rotatoria: Die Rädertiere Mitteleuropas: Ein Bestimmunswerk Bengründet von Max Voigt Überordnung Monogononta.; Gebrüder Borntraeger, Berlin, Stuttgart. 234 p., 1978.

Fontaneto, D.; De Smet, W. H. Rotifera. In Handbook of zoology Gastrotricha, Cycloneuralia and Gnathifera.Vol 3; Rhaera, A. S., Ed.; De Gruyter-GmbH, Berlin, 2015; pp 217-196.

Elías-Gutiérrez, M; Suárez-Morales, E; Gutiérrez-Aguirre, M. A; Silva-Briano, M; Granados-Ramírez, J. G y Garfias-Espejo, T. Cladocera y Copepoda de Las Aguas Continentales de México. Guía Ilustrada; México, México, Universidad Autónoma de México. 322 p.: México, 2008.

Suarez-Morales, E.; Gutiérrez-Aguirre, M. A.; Gómez, S.; Perbiche-Neves, G.; Previattelli, D.; Dos SantosSilva, N.; da Rocha, C. E. F.; Mercado-Salas, N. F.; Manriquez, T. M.; Cruz-Quintana, Y.; Santana-Piñeros, A. M. Class Copepoda. In Thorp and Covich's Freshwater Invertebrates: Volume 5: Keys to Neotropical and Antarctic Fauna; Damborenea, C., Rogers, C. D., James, T., Eds.; San Diego, United States, Elsevier Science Publishing Co Inc., 2020; p 1046.

Pérez, L.; Bugja, R.; Lorenschat, J.; Brenner, M.; Curtis, J.; Hoelzmann, P.; Islebe, G.; Scharf, B.; Schwalb, A. Aquatic Ecosystems of the Yucatán Peninsula (Mexico), Belize, and Guatemala. Hydrobiologia 2011, $661(1), 407-433$.

Gutiérrez-Aguirre, M. A.; Reid, J. W.; Suárez-Morales, E. An Afro-Asian Species of Mesocyclops (Copepoda: Cyclopoida) in Central America and Mexico. J. Crustac. Biol. 2003, 23 (2), 352-363.

Reid, J. W. Arctodiaptomus dorsalis (Marsh): A Case History of Copepod Dispersal. Banisteria 2007, 1860 (30), 3-18.

Juday C. Limnological Studies on Some Lakes in Central America. Wisconsin Acad. Sci. Arts, Lett. 1915, $214-250$.

Gutiérrez-Aguirre, M. A.; Suárez-Morales, E. The Eurasian Thermocyclops crassus (Fischer, 183) (Copepoda, Cyclopoida) Found in Southeastern Mexico. Crustaceana 2000, 73 (6), 705-713.

Frutos, S. M.; Poi, A. S. G.; Neiff, J. J. Zooplankton Abundance and Species Diversity in Two Lakes with Different Zooplankton Abundance and Species Diversity in Two Lakes with Different Trophic States (Corrientes, Argentina) Abundância e Diversidade Específica Do Zooplâncton Em Dois Lagos. Acta Limnol Bras 2009, 21 (3), 367-375.

Gama Flores, J. L.; Sarma, S. S. S.; López Rocha, A. N.; Nandini, S. Effects of Cladoceran-Conditioned Medium on the Demography of Brachionid Rotifers (Rotifera: Brachionidae). Hydrobiologia 2018, 844 (1), 21-30. https://doi.org/10.1007/s10750-018-3853-z.

Cervantes-Martínez, A. Análisis Limnológico de Dos Sistemas Cársticos (Cenotes) de La Península de Yucatán, México Con Énfasis En La Variación Espacial y Temporal Del Zooplancton, Tesis de Doctorado, El Colegio de la Frontera Sur, Chetumal, México. 171 p., 2005.

Papa, R. D. S.; Li, H.; Tordesillas, D. T.; Han, B.; Dumont, H. J. Massive Invasion of Arctodiaptomus dorsalis (Copepoda, Calanoida, Diaptomidae) in Philippine Lakes: A Threat to Asian Zooplankton Biodiversity? Biol. Invasions 2012, 14 (12), 2471-2478.

(C) 2020 by the authors; licensee MDPI, Basel, Switzerland. This article is an open access article distributed under the terms and conditions of the Creative Commons by Attribution (CC-BY) license (http://creativecommons.org/licenses/by/4.0/). 